Електронне наукове фахове видання "Ефективна економіка" включено до переліку наукових фахових видань України з питань економіки (Категорія «Б», Наказ Міністерства освіти і науки України від 11.07.2019 № 975) www. economy.nayka.com.ua | № 2, 2021 | 25.02.2021 p.

DOI: $\underline{10.32702 / 2307-2105-2021.2 .85}$

UDC 005.32:[331.101.3+331.104.2]

\author{
D. Butenko \\ $P h D$ in Economics, \\ Associate Professor of the Department of Entrepreneurship \& Hotel and Restaurant Business, \\ Simon Kuznets Kharkiv National University of Economics \\ ORCID ID: 0000-0001-7027-7767 \\ K. Nemashkalo \\ Doctor of Philosophy (PhD in Economics), \\ Associate Professor, Associate Professor of the Department of Management and Business, \\ Simon Kuznets Kharkiv National University of Economics \\ ORCID ID: 0000-0002-8614-750X
}

\title{
CORPORATE CULTURE AS A COMPONENT OF MOTIVATIONAL MANAGEMENT
}

\author{
Д. С. Бутенко, \\ к. е. н., дочент, дочент кафедри підприємництва та готельно-ресторанного бізнесу, \\ Харківський національний економічний університет імені Семена Кузнеия \\ К. Р. Немашкало, \\ доктор философії (к.ее. н.), дочент, доцент кафедри менеджменту і бізнесу, \\ Харківський національний економічний університет імені Семена Кузнечя

\section{КОРПОРАТИВНА КУЛЬТУРА ЯК СКЛАДОВА МОТИВАЦЙНОГО МЕНЕДЖМЕНТУ}

The personnel of the enterprise is the main resource of the organization, because the efficiency of entrepreneurial activity depends on the result of the activity of workers and employees. It is possible to increase labor productivity and make full use of human resources by building an effective system of staff motivation. The corporate culture of the organization plays a significant role in the development of motivational management. Therefore, the issues related to its formation and successful use are of great importance. Thus was formed the purpose of the article: a theoretical study of the process of formation of corporate culture and ways to adapt it to the activities of the organization. The purpose of the article is a theoretical study of aspects of the formation and implementation of corporate culture in the system of motivational management of the organization. To achieve this goal, the following tasks are set and solved in the article: the stages of development of the concept of "corporate culture" are considered and generalized; the existing points of view on the essence of the concept of "corporate culture" are analyzed; the components of corporate culture are considered; the purpose and tasks of corporate culture are formed; the principles and functions of corporate culture are listed; the existing classification of corporate culture is generalized.To achieve this goal, the following research methods were used: theoretical generalization, analysis and synthesis - to clarify the concept of "corporate culture" and to generalize the classification of corporate culture. System approach - to determine the relationship between corporate culture and the effectiveness of motivational management. Historical method - to 
identify stages of development of corporate culture. The main findings of the article are the five stages of corporate culture. From the first use of the term to the scientific substantiation of corporate culture models. The study showed that corporate culture should be considered as part of the management system of the organization. To facilitate understanding of the content and role of corporate culture, its types were considered and generalized into a single classification.

Значну роль в розвитку мотивачійного менеджменту відіграє корпоративна культура організаиії. Тому питання, пов'язані з ї̈ формуванням та успішному використанні мають велике значення. Так було сформовано мету статті: теоретичне дослідження прочесу формування корпоративної культури та способів ї̈ адаптації в діяльність організащії. Для досягнення поставленої мети було використано наступні методи дослідження: теоретичного узагальнення, аналізу та синтезу - для уточнення поняття «корпоративна культура» та узагальнення класифікації корпоративної культури. Системний підхід - для визначення взаємозв'язку між корпоративною культурою та ефективністю мотиваційного менеджменту. Історичний метод - для виокремлення етапів розвитку корпоративної культури.

Стаття присвячена дослідженню корпоративної культури та ї̈ впливу на ефективність мотивачійного менеджменту. В статті розглянуто поняття «корпоративна культура» та «корпоративний дух». Наведена еволючія ции понять. Виокремлено п'ять етапів розвитку корпоративної культури. Представлено розмежування понять «організачійна культура» та «корпоративна культура». Розглянуто складові корпоративної культури та розкрито їх зміст. Визначено місце корпоративної культури в системі мотиваційного менеджменту організації. Встановлено мету та основні завдання корпоративної культури. Розглянуто функиї корпоративної культури. Виокремлено дві групи функцій корпоративної культури, а саме: спечифічні та загальні. Дістали подальшого розвитку існуючі класифікації корпоративної культури, щзо на відміну від існуючих враховує наступні ознаки: за об'єктом впливу; за рівнем підтримки; за рівнем пізнання; за специфрікою виду діяльності; за набором иінностей; за рівнем поширення в організаиіі; за динамікою організащійних змін; за ступенем організаиійної міиності. Доведено, щзо в залежності від стратегії розвитку організації необхідно змінювати або адаптувати систему мотивачії персоналу. Приведено принципи корпоративної культури та розкрито їх значення та зміст. Надано рекомендації щодо підвищення ефективності системи мотиваційного менеджменту в організації за рахунок управління корпоративною культурою.

Key words: motivational management; corporate culture; organizational culture; components of corporate culture; motivation system.

Ключові слова: мотиваційний менеджмент; корпоративна культура; організаційна культура; складові корпоративної культури; система мотиваиії.

INTRODUCTION. The experience of developed countries shows that the presence of corporate culture in the organization can be a tool for forming effective motivational mechanisms. Which in turn can increase the level of job satisfaction, increase productivity, enhance the creative abilities of employees and the desire to work for results.

LITERATURE REVIEW. Many works of domestic and foreign scientists are devoted to the issues of motivational management and corporate culture, namely: G. Hofstede [10], Bala O. [1-2], Zakharchyn G. [17], Hayet G.[9], Otenko I. [12], Polyanska A. [13] etc.

Despite the large volume of existing publications, some issues need to be addressed.

LENS PAPER. The purpose of the article is a theoretical study of aspects of the formation and implementation of corporate culture in the system of motivational management of the organization.

METHODOLOGIES. To achieve this goal, the following research methods were used: theoretical generalization, analysis and synthesis - to clarify the concept of "corporate culture" and to generalize the classification of corporate culture. System approach - to determine the relationship between corporate culture and the effectiveness of motivational management. Historical method - to identify stages of development of corporate culture.

RESULT AND DISCUSSION. For the first time the concept of "corporate culture" and "corporate spirit" falls on the end of the XIX - beginning of the XX century. For example, in the scientific literature it is noted that the term "corporate culture" (in the original language - Organisationskultur) was first used in military terminology in the XIX 
century. German Field Marshal Moltke (Helmuth Karl Bernhard Graf von Moltke) to determine the relationship of cohesion in the officer environment. [14].

The founder of the School of Scientific Management, Frederick Taylor, drew attention to corporate culture, highlighting the role of corporate rules, standards in the organization of work and the system of staff incentives. [17].

In the management of "employee cohesion" in the early twentieth century Henri Fayol, the founder of the school of classical management, became interested in the book "General and Industrial Management". Thus, among the basic principles of management, he singles out the corporate spirit. [6].

In 1936, M. Sheriff defined the concept of social norms of behavior of workers, which meant certain models and rules of conduct. [13]

The beginning of the study of the term "corporate culture" is considered to be Max Weber. He saw it as the basis of self-organization of corporations, the relationship of moral and ethical principles and socio-economic well-being of individual corporate structures, and developed a model of "rational organization of free labor" that required strict discipline, accuracy, responsibility and stability. [15].

W. Ouchy also considers corporate culture as a component of the motivational theory "Z", which is based on the unity of people and their sense of belonging to the organization. [15].

The intensification of the processes of analysis of corporate culture is considered to be the 80's of the twentieth century. And the greatest interest of scientists falls on the beginning of the XXI century. this is due to research on human capital, the formation of an innovative economy and the growth of global competition in world markets.

Thus, we can distinguish the stages of evolution of the concept of "corporate culture", which is shown in Fig. 1

\begin{tabular}{|c|c|}
\hline Stage 1 & XIX century - the emergence of the term "corporate culture" (Moltke) \\
\hline \multicolumn{2}{|r|}{$\downarrow$} \\
\hline Stage 2 & $\begin{array}{l}\text { early twentieth century. - awareness of scholars-practitioners in the } \\
\text { need for corporate spirit in the organization } \\
\text { (F. Taylor, A. Fayol, M. Weber) }\end{array}$ \\
\hline \multicolumn{2}{|r|}{$\nabla$} \\
\hline Stage 3 & $\begin{array}{l}70-80 \text { s of the XX century. - scientific understanding of the } \\
\text { relationship between culture and management (management) } \\
\text { (G. Hofstede, P. Turner, T. J. Peters) }\end{array}$ \\
\hline \multicolumn{2}{|r|}{$\nabla$} \\
\hline Stage 4 & $\begin{array}{l}1982 \text { - introduction of the scientific term "corporate culture" of the } \\
\text { organization (T. Dela. A. Kennedv) }\end{array}$ \\
\hline \multicolumn{2}{|r|}{$\checkmark$} \\
\hline Stage 5 & $\begin{array}{l}\text { the beginning of the XXI century - research of models of corporate } \\
\text { culture }\end{array}$ \\
\hline
\end{tabular}

Figure 1. Stages of evolution of corporate culture development

Source: compiled by the author after [15]

Today, interest in understanding the nature and feasibility of corporate culture in the organization is only growing. This is evidenced by publications and scientific works of scientists. [1] Thus, in particular, attention is paid to the distinction between the concepts of "organizational culture" and "corporate culture". Despite the common characteristics of these concepts, which include values and norms of human behavior, scientists have different views on the identity of these concepts. Thus, there are the following points of view on this issue [8]:

the concept of "corporate culture" is identical to the concept of "organizational culture";

the concept of "organizational culture" is more capacious and includes "corporate culture";

corporate and organizational culture are different concepts.

Based on the analysis of the stages of development of "corporate culture", we can conclude that with the evolution of managerial thought, the essence of the concept has changed. Thus, initially the organization was characterized by some goals: a focus on increasing production, and then others: a focus on quality and innovation. Therefore, from the beginning they used the concept of "organizational culture", and later "corporate culture", because they differed in content, namely in the target feature. Today in the scientific literature there are different interpretations of these concepts.

Today there are a large number of interpretations and points of view on the interpretation of the essence of corporate culture. Thus, Hayet G. believes that this is a system of values, beliefs, beliefs, ideas, expectations, symbols, as well as business principles, norms of behavior, traditions, rituals, etc., which have developed in the organization and its units during the activity and which are accepted most employees. [9]. The author focuses on the value system of the organization and cites its components.

And, Bala O., understands corporate culture: "rules of doing business both nationally and internationally, making management decisions, delegating authority, organizing the communication process, improving quality, creating a social climate, etc." [1]. Pays attention to the external environment as a factor influencing the formation of corporate 
culture of the organization. A similar approach to interpretation in M. Semikin and I. Khimich, the authors understand corporate culture as a set of tools to adapt to the requirements of the external environment and the internal environment of the organization, organizational culture creates the necessary conditions and facilitates the collision of the company with environmental requirements. [14].

Kovtun O. states the following: "corporate culture is an ideology that encompasses common values, a sense of belonging to the organization, the integration of goals of staff and business organization, traditions, organizational myths, and is the highest form of cultural development of the organization." [11]. Considers corporate culture in the management system of the organization.

And, for example, G. Hofstede does not provide his own definition of corporate culture, but identifies its components, Fig. 2.

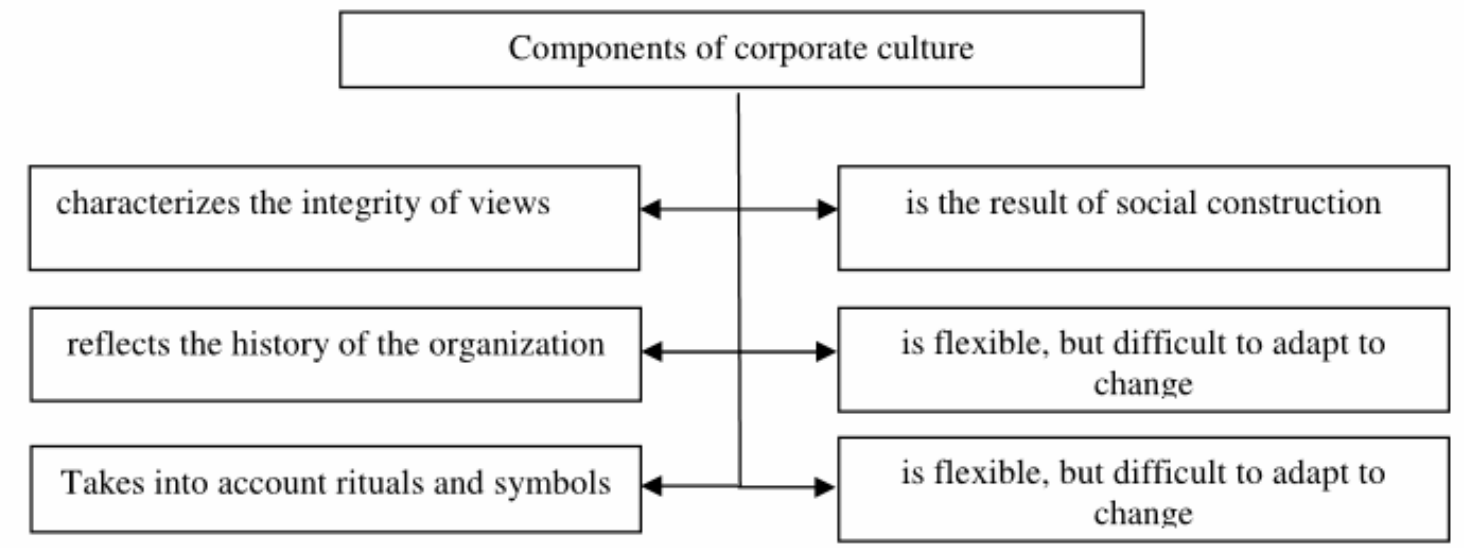

Figure 2. Components of corporate culture according to G. Hofstede Source: compiled by the author after [10]

However, domestic scientists distinguish other components of corporate culture. Thus, Veremchuk R. includes: worldview, organizational values, styles of behavior, norms and psychological climate in the organization. [16]

In turn, Chernyshova A. and Nemchenko T. to the constituent elements of corporate culture include personality qualities: the desire to compete, the ability to persuade; the desire to play the role of an informal leader; tolerance to routine administrative work. [4]

Fisenko E. to the constituent elements of corporate culture includes: mission, values, image, main goals and strategic vision, rules and norms of behavior, traditions, code of ethics. [7]. Thus, the author emphasizes the importance of corporate culture in managing the organization.

Therefore, corporate culture should be considered as part of the management system of the organization. That is, in its formation it is necessary to take into account the strategy of the organization and the impact of corporate culture on the system of staff motivation.

The purpose of corporate culture is to form the behavior of staff taking into account the vectors of the system of motivational management, which contributes to achieving the goals of the enterprise.

To achieve this goal in the process of personnel management of the enterprise it is necessary to solve the following tasks [5]:

development of the staff's sense of involvement in the affairs of the enterprise;

encouraging the involvement of staff in joint activities for the benefit of the enterprise;

strengthening the stability of the system of social relations; support of individual initiative of employees;

assisting staff in achieving personal success; creating an atmosphere of unity of managers and staff at the enterprise;

delegation of responsibility;

strengthening the corporate family (congratulating staff on family, work holidays, events, etc.).

Tasks are performed through the functions of corporate culture. According to Zakharchin GM, the functions of corporate culture reflect not only its essential characteristics, areas of research, but also its importance in the management system. [17]. Domestic scientists divide the functions of corporate culture into two groups: specific and general. Thus, the specific functions of corporate culture include [8; 17]:

creative (creation and preservation of spiritual values);

evaluation-normative (based on the comparison of real human behavior with the accepted norms, the employee is evaluated, his positive and negative actions, progressive or conservative attitude to organizational development are determined);

regulatory and regulatory (based on a preliminary assessment and analysis of the creation of corporate standards and their inclusion in internal regulations, as well as monitoring compliance with these provisions by employees); cognitive (acquisition by employees of new knowledge, knowledge of new sensations, participation in new forms of learning and social work, gaining spiritual and social experience);

semantic (participation of culture in the definition of man and society of the meaning of life, the meaning of their existence, ie personal and social mission); 
communication (through the values accepted by a society, norms of behavior and other elements of culture mutual understanding of members of the organization and their interaction is provided);

function of public memory (preservation and accumulation of experience of human relations in the organization and humanity as a whole.

The general functions of corporate culture include:

protective (educational), which is to create a certain "barrier" or barrier that protects the organization from unwanted and threatening external influences; education of employees in the spirit of devotion to the organization;

integrative or compensatory, which forms a sense of belonging to the organization, pride in it, provides a sense of unity; encourages other people who are not employees of the organization to become its full members;

regulatory or normative-regulatory, which supports (controls) the established norms and rules of conduct of members of the organization, their relationships with each other, with representatives of other organizations and in general with the outside world; all this is a condition for maintaining the stability of the organization, reduces the possibility of conflicts;

guiding, which is manifested in the direction of employees and the organization to achieve the goals and objectives;

motivational, which consists in creating incentives for the orientation of employees in the right direction;

cognitive and informational, providing the process of forming a system of knowledge of the organization;

game and symbolic, which contribute to the formation of the system of internal communications in the organization;

adaptive, which facilitates the process of adaptation of employees to each other and to the organization through established norms and rules of conduct, traditions, participation in joint activities; promotes the socialization of new employees;

the function of forming the image of the organization, which is to create a certain image of the organization in the social environment.

To facilitate understanding of the content and role of corporate culture, it is necessary to consider its types. In the scientific literature there are classifications on various grounds.

The generalized classification of corporate culture is presented in table. 1.

Table 1.

Classification of corporate culture

\begin{tabular}{|c|c|}
\hline Classification feature & View \\
\hline \multirow{4}{*}{ By object of influence } & power culture \\
\hline & role culture \\
\hline & task culture \\
\hline & personality culture \\
\hline \multirow{2}{*}{ By level of support } & strong \\
\hline & weak \\
\hline \multirow{2}{*}{ By level of knowledge } & subjective \\
\hline & objective \\
\hline \multirow{4}{*}{ According to the specifics of the activity } & culture of trade \\
\hline & administrative culture \\
\hline & speculative culture \\
\hline & investment culture \\
\hline \multirow{4}{*}{ By set of values } & clan culture \\
\hline & aphtocratic culture \\
\hline & hierarchical culture \\
\hline & market culture \\
\hline \multirow{3}{*}{ By level of distribution in the organization } & dominant \\
\hline & subculture \\
\hline & counterculture \\
\hline \multirow{2}{*}{ According to the dynamics of organizational change } & revolutionary \\
\hline & evolutionary \\
\hline \multirow{2}{*}{ According to the degree of organizational strength } & inflexible \\
\hline & flexible \\
\hline \multirow{3}{*}{ Depending on the development strategy } & progressive \\
\hline & regressive \\
\hline & borrowed \\
\hline
\end{tabular}

Source: compiled by the author after [3; 16; 17] 
To develop and implement a corporate culture, it is necessary to follow a number of principles, fig. 3

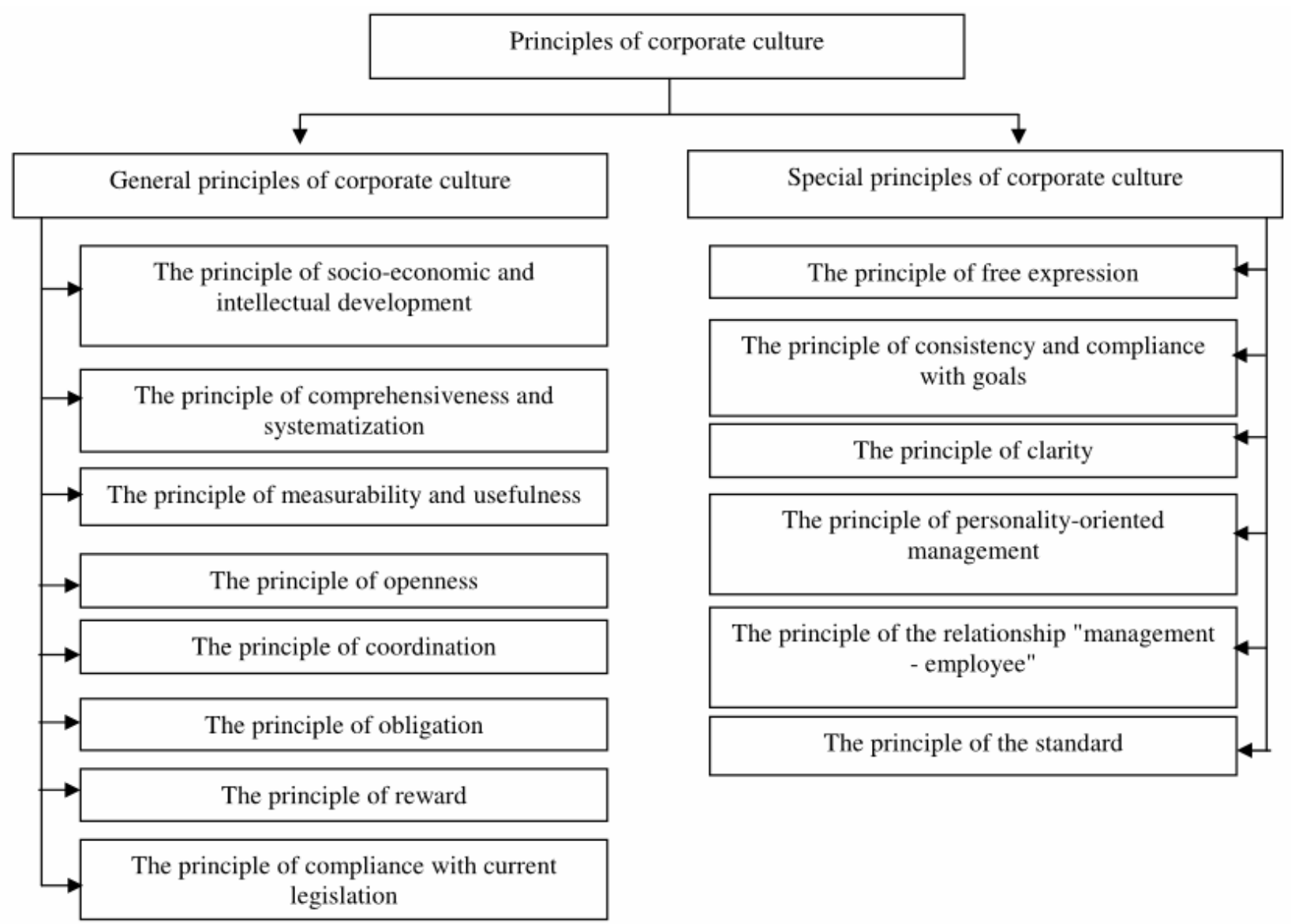

Figure 3. Principles of corporate culture

Source: compiled by the author after [2]

Thus, compliance with the principles of corporate culture should ensure the orientation of the motivational system on economic prosperity, social and intellectual development of all employees of the organization. Also take into account the interests of both workers and the organization as a whole. According to these principles, corporate culture should be flexible and change depending on the external environment. The role of management in monitoring the implementation of corporate culture is important, namely in analyzing its impact on the system of staff motivation and compliance with established norms for employees.

CONCLUSION. One of the main tools for building an effective system of motivation is corporate culture. The theoretical analysis showed that corporate culture has certain components, namely: values, behavioral styles, norms and psychological climate in the organization and so on. When forming a corporate culture, it is necessary to adhere to certain principles, which will provide a positive effect after its implementation.

\section{REFERENCES.}

1. Bala, O.I. (2009), "Economic evaluation and development of corporate culture of machine-building enterprises", Abstract of Ph.D. dissertation, Economy, Lviv Polytechnic National University, Lviv, Ukraine.

2. Bala, O.I. Mukan, O.V. and Bala, R.D. (2010), "Principles of corporate culture of enterprises: essence and types”, Visnyk Natsional'noho universytetu «L'vivs'ka politekhnika», vol. 682, pp. 11-15.

3. Balika, O.G.(2014), "New approaches to the classification of corporate culture in the context of its impact on social and labor relations", Naukovyj visnyk Poltavs'koho universytetu ekonomiky i torhivli, vol. 1, pp.156-161.

4. Chernyshova, A.A. and Nemchenko, T. A. (2010), "Some aspects of corporate culture of the organization", Naukovi pratsi KNTU, vol. 17, available at: http://www.kntu.kr.ua/doc/zb_17_ekon/stat_17/49.pdf (Accessed 10 Feb 2021).

5. Dolga, G.V. (2018), "Influence of corporate culture on personnel management of the enterprise", Modern Economics, vol. 7, pp.60-67.

6. Fayol, H. (1923), "General and industrial management", available at: http://gtmarket.ru/laboratory/basis/5783 (Accessed 10 Feb 2021).

7. Fisenko, E.S. and Malyk, I. P. (2016), "Corporate culture as a factor in increasing the competitiveness of the enterprise", Aktual'ni problemy ekonomiky ta upravlinnia, vol. 10, available at: http://ape.fmm.kpi.ua/article/view/66920 (Accessed 10 Feb 2021). 
8. Gnezdilova, K.M. (2013), Korporatyvna kul'tura vykladacha vyschoi shkoly : navch.-metod. posibnyk [Corporate culture of a high school teacher: teaching method. Manual], ChNU imeni Bohdana Khmel'nyts'koho, Cherkasy, Ukraine.

9. Hayet, G.L. (2003), Korporatyvna kul'tura [Corporate culture], Tsentr navchal'noi literatury, Kyiv, Ukraine.

10. Hofstede, G. (1991), Culture's Consequences: International Differences in WorkRelated Values, Sage, Newbury Park, USA.

11. Kovtun, O.S. (2013), "Formation of corporate culture of economic organization in the conditions of transit society”, Ukrains'kyj sotsium, vol. 3, pp. 54-62.

12. Otenko, I.P. and Chepeliuk, M. I. (2018), Korporatyvna kul'tura: mizhnarodnyj ta transformatsijnyj aspekty : monohrafiia [Corporate culture: international and transformational aspects: monograph], KhNEU im. S. Kuznetsia, Kharkiv, Ukraine.

13. Polyanska, A.S. and Diuk, O.M. (2018), "Formation of the model of corporate culture in the activity of domestic enterprises", Prychornomors'ki ekonomichni studii, vol. 27, pp.9-16.

14. Semikina, M.V. (2018), Rehuliuvannia konkurentospromozhnosti u sferi pratsi : monohrafiia [Corporate culture in the system of social and labor relations: Monograph], MAVIK, Kirovohrad, Ukraine.

15. Vasiliev, A.Y. and Kharchevnikova, L. S. (2016), "Influence of corporate culture on the efficiency of the enterprise", Visnyk Kharkivs'koho natsional'noho tekhnichnoho universytetu sil's'koho hospodarstva imeni Petra Vasylenka, vol. 176, pp.44-52.

16. Veremchuk, R.O. (2006), "Corporate culture of the organization and its impact on the personnel development system", Visnyk Natsional'noho universytetu «L'vivs'ka politekhnika». Problemy ekonomiky ta upravlinnia, vol. 554, pp. 240-245.

17. Zakharchin, G.M. Liubomudrova, N.P. Vynnychuk, R.O. and Smolins'ka, N.V. (2018), Korporatyvna kul'tura: Navchal'nyj posibnyk [Corporate culture: Textbook], L'viv, Ukraine.

Стаття надійшла до редакиії 15.02.2021 p. 